\title{
IMPLEMENTING BILINGUAL STORY-TELLING PICTURE BOOK TO REINFORCE CHARACTER EDUCATION FOR PRE-SCHOOLERS IN ENGLISH EXTRACURRICULAR ACTIVITY
}

\author{
Triastama Wiraatmaja ${ }^{1}$, Agista Nidya Wardani ${ }^{2}$, Kharisma Naidi Warnanda S. ${ }^{3}$ \\ 1,2,3 University of Muhammadiyah Malang \\ ${ }^{1}$ triastama@umm.ac.id, ${ }^{2}$ agista@umm.ac.id, ${ }^{3}$ kharisma.naidi@umm.ac.id
}

\begin{abstract}
Reinforcing character education in the early childhood education or preschooler was deemed important nowadays; however, in order to do so it requires creative yet unique method to pique young pupils' interest. Therefore, this research intends to elaborate the idea of reinforcing character education by implementing Bilingual Story-Telling Picture Book towards the pupils at one of the preschoolers located in Malang, East Java. This Bilingual Story-Telling Picture Book was composed specifically to teach the students about character education by integrating it with one of extracurricular activities in this school, the English language extracurricular activity. Therefore, this Bilingual Story-Telling Picture Book attempted to not only reinforcing the young pupils' character education in story telling activity, but also improving their literacy and interest towards English language. Thus, the results indicate that the students were keen on learning English on the story-telling activity delivered by the teacher in charge whilst absorbing the value of character education delivered by the book.
\end{abstract}

Keywords: Story-Telling Picture Book, Extracurricular Activity, Character Education, Pre-Schoolers

\section{INTRODUCTION}

Reinforcing character education was deemed pivotal in enriching and strengthens children's characters for the foreseeable future. Since nowadays children at very young age are already exposed to the use of gadgets, and lack of parents' supervisions, eventually led to children misbehaviours. In other words, this stage is exceptionally critical and determining periods that define someone's attitude, values, and behaviours in the future; in which it requires proper stimulation(Widyastuti \& Handayani, 2020). Character education itself has purposes to shape a person's future by providing them an ongoing and relentless process to emulate and to initiate the young pupils understanding regarding positive habits, good morality, and pious personality or aqeedah, so they would get accustom with the notion of good and bad deed without having to be told. The process of educating the value of character education was the perpetual process of making those value into habit, not only teach the notion of right or wrong to young children but also teach the young children to understand, and to perform good deeds and avoid bad deed without having to be told (A. Kamaruddin, 2012).

In addition, as we are all aware that character education is a tedious, strenuous and requires lot amount time to be fully understood by any individuals, besides character education's notion is not only transferring the value but instilling good habits to help shape child's identity also (Nurussa'adah, 2014) 
Therefore, to constitute better understanding on how to reinforcing the young pupils character development, the researchers keen on composing a picture book in English and bahasa so it would be able to intrigue their curiosity towards picture book. Besides, the use of picture book as one of literary texts offers several benefits in teaching language and the concept of morality towards the pupils' development. As literary texts, notably picture book, offer several benefits in teaching language and the concept of morality (Tasneen, 2010), first students will experience linguistics exposures to real and authentic usage of language in literary texts, second methodological aspects of literary texts that provide various interpretation and offer numerous chances for students' interaction, and lastly the motivational reasons of the literary texts that resemble the writer's genuine idea regarding every aspects in life.

Utilising Story-Telling picture book would be an interesting means to educate the pupils about English while having creative thinking, self-confidence, high literacy level, and all that also embedded by reinforcing character education during the extracurricular activity. Due to the fact that literature possesses various traits (Ur, 1996); literature regarded as a enjoyable method to learn language, literature provides exemplary and authentic usage of writing style of the language, literature also able to deliver emotional and intellectual values, and literature encourages students' understanding of critical and creative thinking as well.

In addition, early childhood education sole purpose was to develop every aspects in child's development, not only the educational aspects but also the child's primary needs; character education (Nurussa'adah, 2014). Thus, by reinforcing character education by implementing Telling-Story Picture book among preschoolers extracurricular activity not solely emphasise on the pupil's character development, yet it was able to improve their keen sense of literacy towards book and good understanding towards English language as well.

\section{METHOD}

Firstly, after Focus Group Discussion session between the researchers with the school's representatives; the headmaster and English teacher. The research team then had deep and thorough discussion regarding the idea of reinforcing character education in the picture books with the headmaster as well, since the headmaster is an expert in psychological fields. Afterwards, the research team and the school's representatives then decided on a certain topic to be the highlight of the picture books.

Next, the research team had written down the script or the idea of the story under the supervision of the school's representatives, especially the idea of reinforcing character education. After the school gave the green lights, the research team then created the raw draft of the books that soon would be given to illustrator. After the book was done, the research team will monitor the teaching of English using picture books that already reinforced with character education, usually the English teacher would employ telling-story method in front of the class.

This present research was performed at PAUD Surya Gemilang, in Malang City, East Java, Indonesia. The school that recently established in early 2019 was also one of the field laboratories under the supervisory of Faculty of Psychology of one of private Islamic university in Malang. However, the Achilles' heel of this research was that during Covid-19 it was difficult to manage and maintain discussion between the research team and the school's representatives. The other one was that since Covid-19, the students were not allowed to attend school so it would be challenging on how to monitor the progress of English extracurricular activity using picture books that already reinforced with the notion of character education. So, the researcher 
had to rely on the teacher's feedback regarding the usefulness and the benefits of utilising the Story-Telling Picture Book during distance or online learning.

\section{RESULTS AND DISCUSSION}

\section{Results}

This research emphasised on the composing of Story-Telling Picture Book for pre-schoolers to reinforce the young pupil's character education. Firstly, the researcher arranged Focus Group Discussion with the school's representatives; the headmaster and the teacher in charge. The purpose of this activity was to gain information and understanding regarding how to reinforce character education using picture book, and combine it with the school's English language extracurricular activity; story telling.

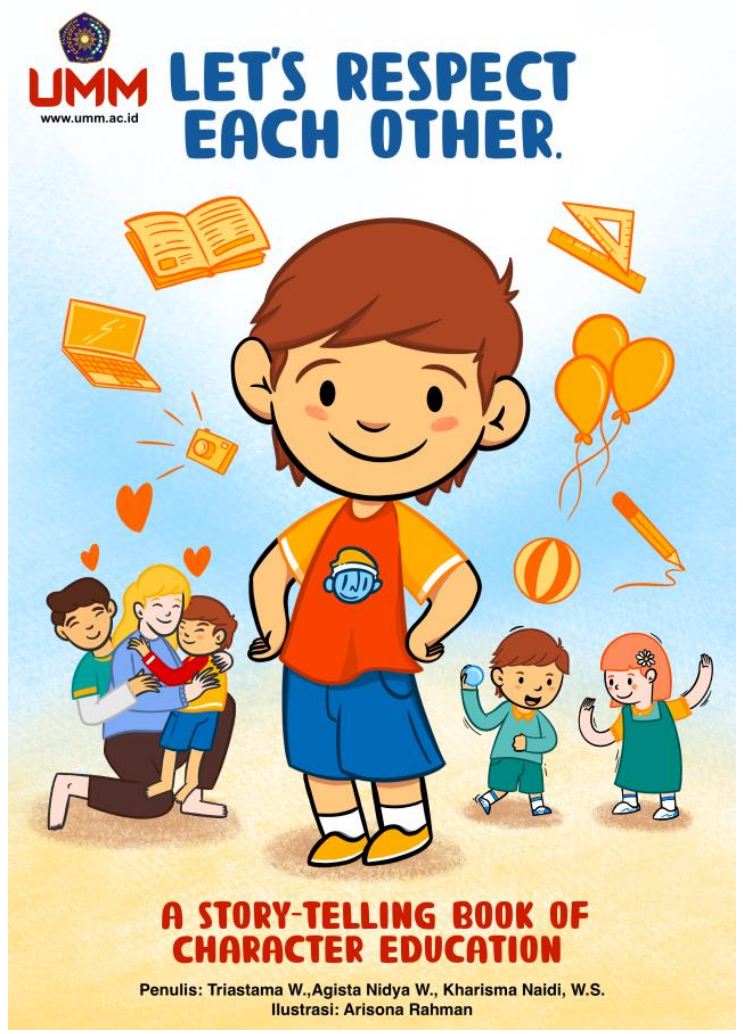

Figure 1. Cover of Let's Respect Each Other Story-Telling Picture Book of Character Education

Afterwards, some documents were required to be analysed for this programs. Especially some reading materials owned by the school, thus, the researcher and the school's representatives would be able to determine the suitable concept for the picture book based on the concept of how to make a prose or narrative text, and the distinctive quality with other reading materials. 

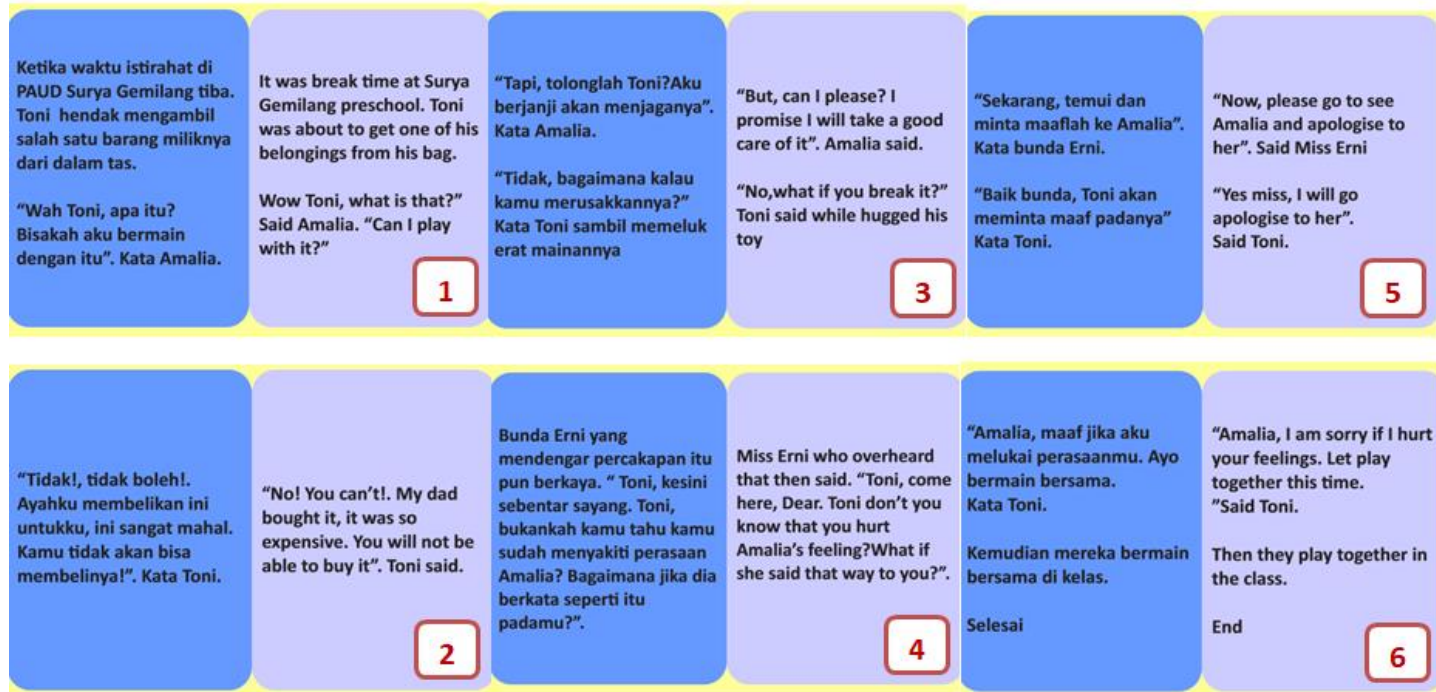

"Amalia, I am sorry if I hurt your feelings. Let play together this time. "Said Toni. Then they play together in the class. End

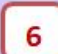

Figure 2. Plot of Let's Respect Each Other Story-Telling Picture Book of Character Education

The above picture shows that the story-telling picture book is made based on plot of a prose or narrtive text: (1) exposition, (2) Climax, (3) Climax, (4) and (5) denouement, and (6) conclusion. Besides, it can be seen that the story is enriched with main character and supporting characters who are close to the pupils' surroundings. Additionally, the setting is also chosen to be the place and time which are familiar to the pupils.

The researchers also investigated the curriculum used in the school as guidance for the researchers in composing the picture book, and the principal aspect found in the curriculum is in the religious aspect, more importantly the development of character education.

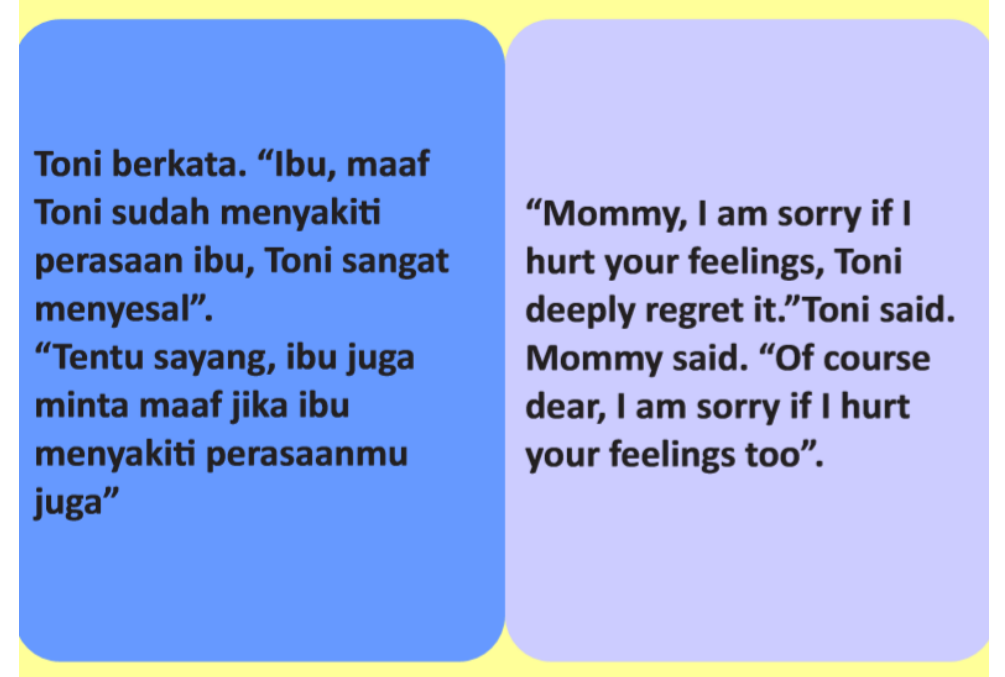

Figure 3. A part of Let's Respect Each Other Story-Telling Picture Book of Character Education about respecting parents 


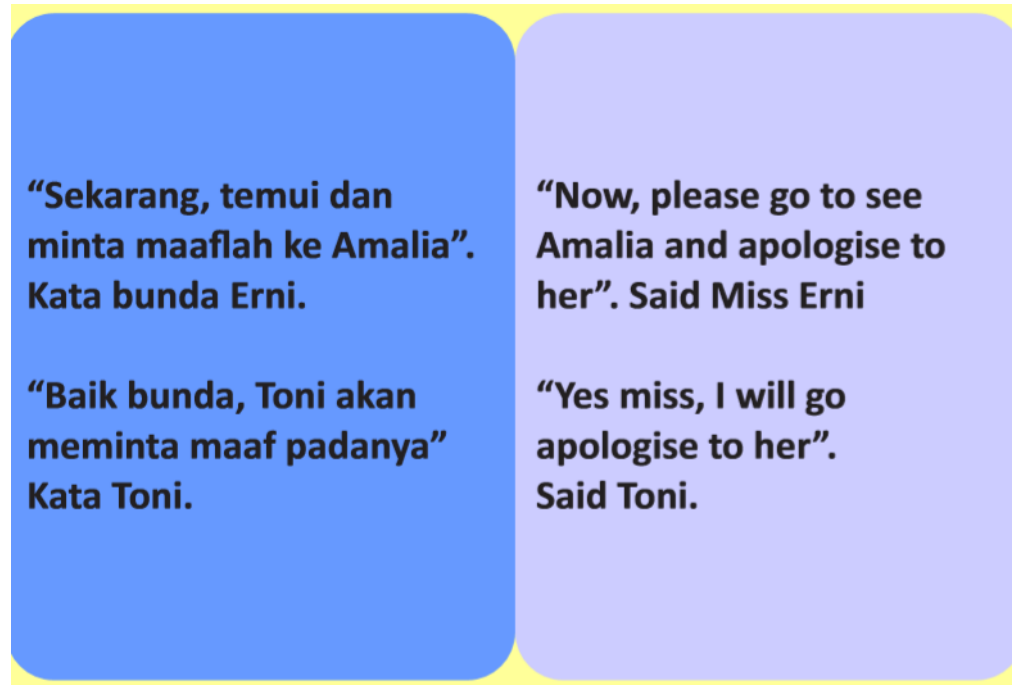

Figure 4. A part of Let's Respect Each Other Story-Telling Picture Book of Character Education about respecting friends

From the two pictures, it is seen that the story is inserted character education in which the pupils are exposed to how respect their parents and friends.

In addition, this book also available in bilingual mode; English and Bahasa Indonesia.

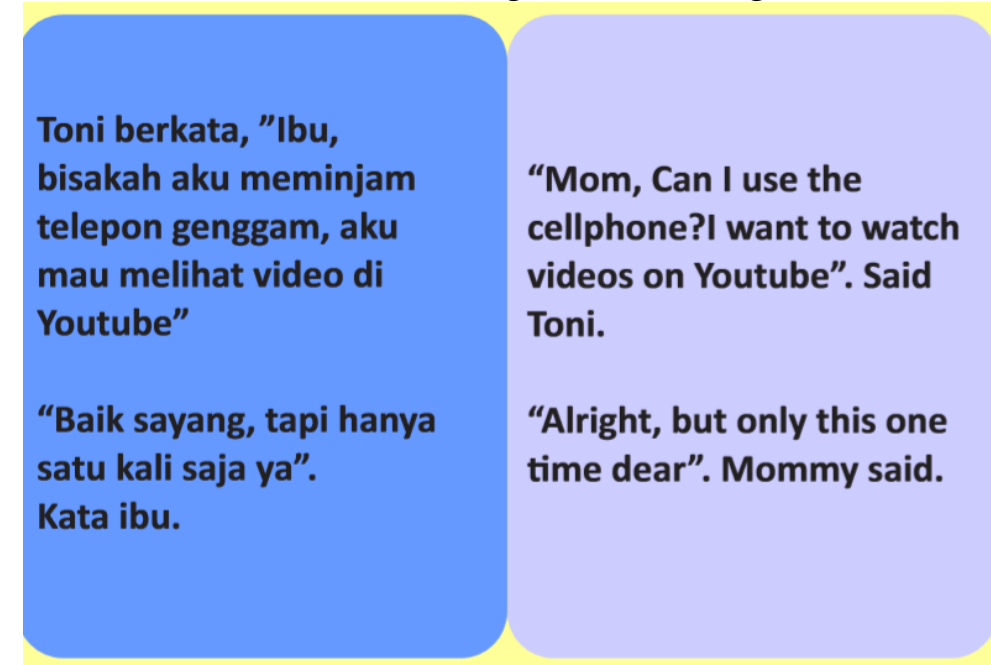

Figure 5. A part of Let's Respect Each Other Story-Telling Picture Book of Character Education written in English and Bahasa Indonesia

On the above example of part of the book, it is seen that the story is written bilingual, in English and Bahasa Indonesia. The bilingual story is intentionally made to ease both pupils and teachers to understand the story in both languages. Thus, the pupils can learn English as well as their mother tongue, Bahasa Indonesia.

Regarding to the layout, this book is designed supporting the story-telling activity. 


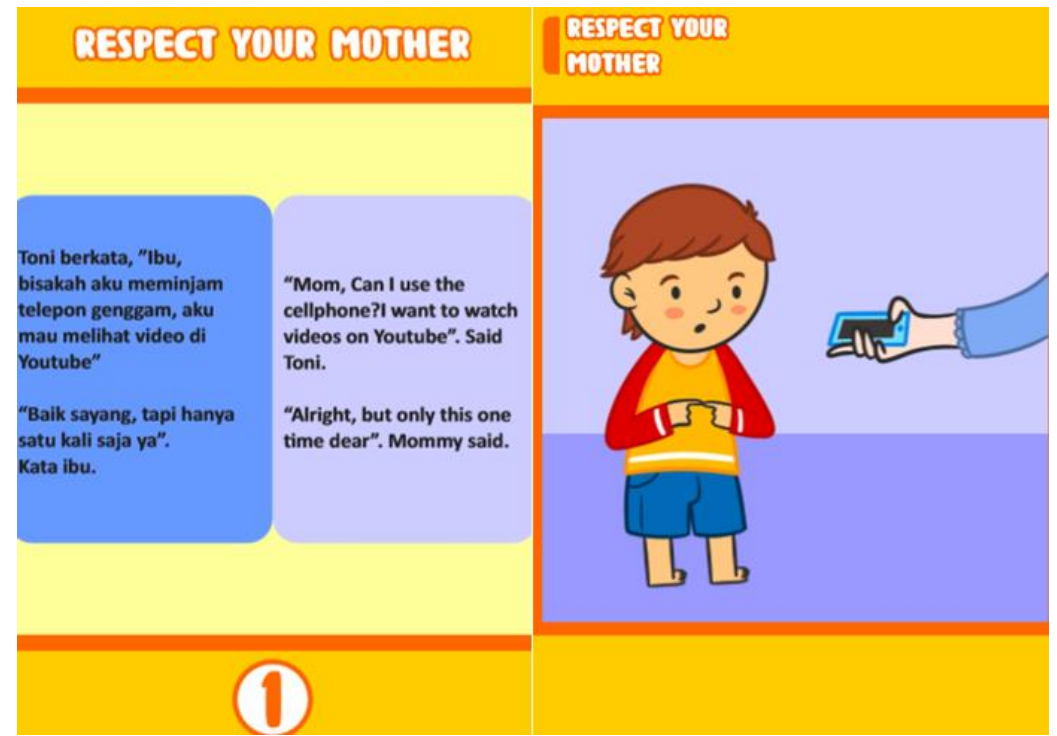

Figure 6. A part of Let's Respect Each Other Story-Telling Picture Book of Character Education showing picture and writing separated to different pages

The picture shows that the pictures and writings of the story in this book are put in different pages. It is made in order to ease both pupils and teachers. The picture side will be shown to the pupils who listen to the story, while the writing side will be shown to the teachers who tell the story. This layout is suitable for a story-telling book.

Afterwards, the process continued by writing down the scripts of the picture book. This stage was done under the supervision of the headmaster who was an expert in child's psychological development and the English teacher.

\section{Discussion}

This research emphasised on the composing of Story-Telling Picture Book for preschoolers to reinforce the young pupil's character education. Firstly, the researcher arranged Focus Group Discussion with the school's representatives; the headmaster and the teacher in charge. The purpose of this activity was to gain information and understanding regarding how to reinforce character education using picture book, and combine it with the school's English language extracurricular activity; story telling. The researchers keen on delivering the notions of character education through the English story telling activity because it is easier to deliver the value of character education through real-time activity that requires' the pupil's attention, whether physically and cognitively. As (Nurussa'adah, 2014) stated that, contextual learning process that includes physical activity provide more comprehensive results not only on the cognitive level but also the pupil's psychomotor development.

Afterwards, some documents were required to be analysed for this programs. Especially some reading materials owned by the school, thus, the researcher and the school's representatives would be able to determine the suitable concept for the picture book, and the distinctive quality with other reading materials. The researcher also investigated the curriculum used in the school as guidance for the researchers in composing the picture book, and the principal aspect found in the curriculum is in the religious aspect, more importantly the development of character education. In addition, this book also available in bilingual mode; English and Bahasa Indonesia. Besides, the researcher focuses on composing and developing reading materials because in this time of year young pupils are easily exposed to gadgets in their daily life. However, excessive amount of use of gadget might lead to gadget addictions, in which, it might influenced the children's cognitive, health, and character development(Bastian et al., 2019). In 
addition, young pupils' development are the foundation their future education since there are two major aspects in education that possess great influence to the young pupils' development; character development and surroundings(Hartono et al., 2019). Therefore, the researchers purpose here also to reduce the child's exposure towards gadgets, as well as improving their literacy skills synchronously, and nurture their interest towards English language as well.

Additional reason for this because the researchers' deemed that early childhood education is critical and sensitive period that influence the pupil's perspective in the future, therefore proper care and attention in giving the stimulation should be a priority, and it was done by composing Story-Telling Picture Book suitable for their needs. Therefore, the researchers were keen on composing the book as a stimulation that helps to shape the young pupil's attitude, behaviour and emotional development as well. Accordingly, strengthening pupil's emotional aspects might help in reducing their aggressive behaviour in the future, because hampered emotional development and social behaviour may led them to resort to violence as a form of anti-social behaviour (Widyastuti \& Handayani, 2020).

Afterwards, the process continued by writing down the scripts of the picture book. This stage was done under the supervision of the headmaster who was an expert in child's psychological development and the English teacher. Here, both of the researchers and the school's representatives emphasise that without proper care, attention, and suitable stimulations, child's character education might go disarray, especially if the child was exposed to gadgets. Besides, children with gadget addiction might expresses lack of creativity, selfishness, less attentive, lack understanding of religious and moral values, and showing anti-social traits. In addition, gadget addiction affected children's physical development as well, since excessive use of gadget lead to obesity and reduce eyes' health(Munawar \& Nisfah, 2020). For that reason, the researchers keen on composing a book that not only supports their emotional or character education, but also their physical development as well. Since, kid's below six years old, or preschoolers, are classified into Golden Age, this stage was deemed extremely important to the kid's brain development, however, the actual Golden Age which the brain develop the fastest actually lies since pregnancy until the infant is four years old (Hartono et al., 2019). Therefore, extra attention must be given during these stage in order to maximise the child's physical and psychological development, including the character development.

Lastly, due to pandemic, Covid-19, the activity of delivering the notion of character education of Story-Telling Picture Book was done by the teacher during online learning. The researcher at the beginning this program keen on utilising Story-telling activity in the English extracurricular activity to encourage the teacher, and the parents as well to physically involved in delivering the idea of the book. In addition, the purpose of this program was to encourage the parents to reduce the exposure of gadgets to their children, because there were high possibility that the excessive use of gadget towards children might negatively influenced their cognitive, health, and character development(Bastian et al., 2019). This activity initially was intended to gather some feedback regarding the book itself from the perspective of the teacher and the parents; however, Covid-19 forced the researchers to rely on teacher's feedback when teaching online which was by providing them with storytelling activity using the book. Recent change of implementing the book to online teaching itself was done under meticulous and thorough discussion due to Covid-19, and both of the researchers and the teacher had to adjust to this kind of learning strategy as effective as possible. However, this learning strategy that adapt to the latest circumstances still prioritising the most effective and efficient method to deliver the material (Kurniasih et al., 2014). 
The importance of childhood education must be a priority during pandemic, since it was difficult to teach in conventional manners, education system had to adjust to online learning. However, excessive use of gadget during online learning might also led to negative effects towards children, therefore, this Story-Telling Picture Book provide both of the parents and the teachers of wide-ranging methods of teaching the young pupils regarding the importance of character education. Since childhood education is the gateway before primary education, and the teachers as well as the parents must provide alternative learning methods so the children would not get addicted with gadgets (Pranoto et al., 2014). More importantly, childhood education was also regarded as the important stage to develop the young pupils physical and mental aspects before primary education that was intended to stimulate the children under six years old to prepare before entering primary education(Hartono et al., 2019). For that reason, providing the students in childhood education with proper and appropriate stimulation would increase the young pupils' success rate in understanding about character education.

\section{CONCLUSION}

Based on the activities that had been done for this program, it can be concluded that hopefully by reinforcing character education through reading sources in English extracurricular activity in Surya Gemilang's Preschoolers could assist the teachers to implement character education through reading in story telling activity whilst improving interest, literacy level, talents and skills of the students in English language. Besides, the value of character education that implicitly and explicitly stated in the picture book was also one of ways to expand students' concept of morality as well. Since they are at golden age, and it was a good opportunity to improve their language proficiency and concept of morality as well. In addition, the storytelling activity in online platform using this picture book was expected to assist the parents to reduce the young pupils gadget addiction as well, including preventing obesity and violence or aggressive behaviours.

\section{ACKNOWLEDGMENTS}

This research was funded by Blockgrant of Faculty Teacher Training and Education, University of Muhammadiyah Malang, Indonesia.

\section{REFERENCES}

A. Kamaruddin, S. (2012). Character Education and Students Social Behavior. Journal of Education and Learning (EduLearn), 6(4). https://doi.org/10.11591/edulearn.v6i4.166

Bastian, A., Suharni, \& Novitasari, Y. (2019). Permainan Tradisional Berbasis Budaya Melayu dalam Pengembangan Karakter Anak. Atfālunā: Journal of Islamic Early Childhood Education, 2(2). https://doi.org/10.32505/atfaluna.v2i2.974

Hartono, T., Rochman, F. S., \& Fikri, W. N. (2019). Implementasi Metode Pembiasaan Modelling Perspektif Teori Behaviorisme di RA Syamila Kids Kota Salatiga. ThufuLA: Jurnal Inovasi Pendidikan Guru Raudhatul Athfal, 7(2). https://doi.org/10.21043/thufula.v7i2.5985

Kurniasih, E. R., Suliyem, \& Wulandari, S. (2014). Teacher Strategies in Character Education Development in Kindergarten. Indonesian Journal Of Early Childhood Education Studies, 3(2), 94-101.

Munawar, M., \& Nisfah, N. L. (2020). The Effect of Assertive Discipline on Early-Aged Children's Gadget Addiction. Journal of Early Childhood Care and Education, 2(2). https://doi.org/10.26555/jecce.v2i2.1002 
Nurussa'adah, N. (2014). Implementation of Learning Management Model of Character Education in Early Childhood in Tarbiyatul-Athfal (TA) Semarang. Indonesian Journal Of Early Childhood Education Studies, 3(2), 118-126.

Pranoto, Y. K. S., Sugiyo, S., \& Hong, J. J. (2014). Developing Early Childhood's Character Through Javanese Traditional Game. Indonesian Journal Of Early Childhood Education Studies, 3(1), 54-58.

Tasneen, W. (2010). Literary Texts in the Language Classroom: A Study of Teacher's and Student's Views at International Schools in Bangkok. Asian EFL Journal, 12(4). http://asian-efl-journal.com/PDF/Volume-12-Issue-4-Tasneen.pdf

Ur, P. (1996). A Course in Language Teaching. Cambridge: Cambridge University Press. . Cambridge University Press. . https://sacunslc.files.wordpress.com/2015/03/penny-ur-acourse-in-language-teaching-practice-of-theory-cambridge-teacher-training-anddevelopment-1996.pdf

Widyastuti, T. M., \& Handayani, P. (2020). The Development of Teacher Handbook on Preschool-Aged Children's Aggressive Behavior and IT-Based Solutions. Journal of Early Childhood Care and Education, 2(2). https://doi.org/10.26555/jecce.v2i2.1040 